\title{
Nwizugbe Fertility Scale; the meter of fertility levels.
}

\author{
Nwizugbe Obiageri Ezenwa, PhD. \\ Is the Senior Monitoring and Evaluation Advisor, JSI Research \& Training/TSHIP, USAID project.
}

\begin{abstract}
Female fertility has been described as the ability of a woman to conceive or become pregnant after a sexual intercourse with a fertile man, irrespective of whether the pregnancy is carried to full tern, ended up in an abortion or still birth. The pregnancy history of a woman from the age of first menstrual period to menopause is described as her Total Fertility. The Total fertility rate (TFR), sometimes also called the fertility rate of a population, is the average number of children that would be born to a woman over her lifetime if she were to observe the prevailing age specific fertility rate (ASFR) and survive from birth through the end of her reproductive life.
\end{abstract}

In 2005, a study on fertility level preferences by women in eight communities in Orsu Local Government Area of Imo State was conducted, and result showed that the fertility levels of the women in the studied communities were dropping down from being very high ( 7 children per woman) towards what could be described then as government promoted fertility levels (4 children per woman). This was a birth control measure imposed by the biting economic conditions of the time. According to Iloegbunam (2011), this was due to "the gross mismanagement of the economy under IBB administration. This administration blew billions of naira beyond computation in a tedious political transition programme that culminated with his nullification of the best presidential election ever conducted in this country. The obvious option was that couples were voluntarily compelled by their own economic hardships to reduce the number of children they wanted; but to what level?

In order to further examine the fertility preferences for the women of south eastern Nigeria, this researcher therefore replicated the study done in 2005 in Imo State, but increased the coverage area to include wider communities selected from Imo and Abia States. The results that were achieved were relatively similar. Nevertheless, the question being asked is; how does the professional statistically categorize the fertility status of the women? Is it sufficient to claim that fertility level is low, or high? What is the yardstick to measure low or high? In order wards, how low or how high? It is an attempt to answering this question that led the researcher to compare the observed fertility trend with the Global fertility levels. He found a very close similarity in both patterns. He found that fertility trend globally is moving from very high to low levels and this is conditioned by urbanization and technological advancement. The less advanced or developed countries still maintain very high fertility levels with tendency to drop to low levels, while the highly developed countries have low fertility levels and struggle to keep it not to go extinct, because the urge to drop to replacement level or zero fertility is eminent.

The author then constructed a scale upon which couples globally could decide on their fertility performance vis-à-vis their economic potentials. This he called "Nwizugbe Fertility Scale". He defined fertility scale as a tool used to categorize the fertility status of a couple according to the number of their children. The scale grades fertility status into zero, low, medium, high and very high. It categorized fertility as follows:

\begin{tabular}{|ll|l|}
\hline \multicolumn{2}{|l|}{ Fertility scale } & Score \\
\hline 1. & Zero fertility & 0 (No child). \\
\hline 2. & Low fertility, or replacement fertility & $1-2$ children \\
\hline 3. & Medium fertility & $3-4$ children \\
\hline 4. & High fertility & $5-6$ children \\
\hline 5. & Very high fertility & $7+$ children \\
\hline
\end{tabular}

The arguments in favour of this scale are as follows: Nwizugbe Fertility Scale is a guide to family planning options for the family. This means that couples can be guided to decide how small or how large they would like their family size to be by looking at this scale. To the professional demographers, economists, and population practitioners, this scale has harmonized their divergences of measuring fertility performances, because it has developed a universal statistical quantum to different fertility categories. To the policy makers, the scale serves as an indicator towards policy options that guide population growth rate. The scale can act as a population growth alert to the Global Communities. 


\section{Introduction:}

Fertility scale cannot be discussed without letting the reader understand what fertility means. It is the ability of a woman to conceive or become pregnant after a sexual intercourse with a fertile man. It is important to note that a woman is still fertile even if her pregnancy ends up in a still birth or aborted. The pregnancy history of a woman from the age of first menstrual period to menopause is described as her Total Fertility. The Total fertility rate (TFR), sometimes also called the fertility rate of a population, is the average number of children that would be born to a woman over her life-time if she were to observe the prevailing age specific fertility rate (ASFR) and survive from birth through the end of her reproductive life. It is obtained by summing the single-year age-specific rates at a given time and then multiplying it by 5. (Blake, J. 1981, Wikipedia 2009, James Kaphuka 2011) ${ }^{1-3}$

Note that ASFR is used interchangeably with ASBR. Further illustrations are necessary to make students understand the concept of TFR and ASFR. Therefore the emphasis below cannot be superfluous.

Total Fertility Rate is the sum of the age-specific birth rates (5-year age groups between 10 and 49) for female residents of a specified geographic area (nation, state, county, etc.) during a specified time period (usually a calendar year) multiplied by 5. (Note: This rate estimates the number of children a hypothetical cohort of 1,000 females in the specified population would bear if they all went through their childbearing years experiencing the same age-specific birth rates for a specified time period).

\section{Calculation:}

$\mathrm{TFR}=(\Sigma \mathrm{ASBR}) \times 5$

Where ASBR is each five-year age-specific birth rate defined as

$\frac{\mathrm{Bx} \times 1,000}{\mathrm{PX}}$

Where $\mathrm{Bx}$ is the number of live births to mothers age $\mathrm{x}$ and $\mathrm{Px}$ is the number of resident women age $\mathrm{x}$. The values or age groups represented by Bx are under 15, 15-19, 20-24, 25-29, 30-34, 35-39, 40-44, and 45+.

The values or age groups represented by Px are 10-14, 15-19, 20-24, 25-29,30-34, 35-39, 40-44 and 45-49 years.

The Value 1000 is a constant. This is why it is called a rate.

The sum of these ASBRs is multiplied by 5 because each ASBR represents a five-year cohort of women. That is $(\Sigma$ ASBR $) \times 5=$ TFR.

- The Total Fertility Rate (TFR) is perhaps the most commonly used Standardized

Fertility measure because it is ideal for comparative purposes and is acomprehensive summary measure readily understood, at least as a general.

Therefore a fertile wise woman consciously or unconsciously practices a form of planning to limit the number of children that she eventually has; as "plan-less-ness" may result to her either not having any life baby or having too many of them. This is what brought about the concept of Family Planning, which can simply be defined as the act of guiding a couple to have an adequate number of children, and in the sex combination desired by them. The choice of the number of children by the couple can be guided by a number of principles; including the prevailing economic conditions, cost of living and choice of standard of living and so on. This is what brought about the concept of fertility scale, that is, a demographic construct upon which any given number of family fertility preference can be classified.

\section{Statement of problem:}

In 2005, a study on fertility level preferences by women in eight communities in Orsu Local Government Area of Imo State was conducted, and result showed that the fertility levels of the women in the studied communities were dropping down from being very high ( 7 children per woman) towards what could be described then as government promoted fertility levels (4 children per woman). This was at a period when the Nigerian nation was passing through a period of structural adjustment program; a very hard economic condition imposed on Nigerians characterized by low income levels for the working class, low investments in the economy, closing down of factories, mass retrenchment of workers, lack of opportunities for new employment for young school leavers and low standard of living. During this period, couples considered having many children was no longer a luxury but a great burden (Nwizugbe 2005) ${ }^{4}$. One serious implication of the condition according to the author was that the youths who were in the urban areas could not get jobs to support 
themselves; those working could not earn enough to meet upcurrent expenditure and income remittances to the rural residents drastically reduced.This was due to "the gross mismanagement of the economy under IBB administration. This administration blew billions of naira beyond computation in a tedious political transition programme that culminated with his nullification of the best presidential election ever conducted in this country". (Chuks Iloegbunam, August 2011,) ${ }^{5}$

The obvious option was that couples were voluntarily compelled by their own economic hardships to reduce the number of children they wanted; but to what level?

In order to further examine the fertility preferences for the women of south eastern Nigeria, this researcher therefore replicated the study done in 2005 in Imo State, but increased the coverage area to include wider communities selected from Imo and Abia States. The results that were achieved were relatively similar. Nevertheless, the question being asked is; how does the professional statistically categorize the fertility status of the a woman? Is it sufficient to claim that fertility level is low, or high? What is the yardstick to measure low or high? In order wards, how low or how high is the fertility level? It is an attempt to answering this question that led the researcher to compare the observed fertility trend with the Global fertility levels. He found a very close similarity in both patterns. He found that fertility trend globally is moving from very high to low levels and this is conditioned by urbanization and technological advancement. The less advanced or developed countries still maintain very high fertility levels with tendency to drop to low levels, while the highly developed countries have low fertility levels and struggle to keep it not to go extinct because the urge to drop to replacement level or zero fertility is eminent.

The author then constructed a scale upon which couples globally could decide on their fertility performance vis-à-vis their economic potentials. This he called "Nwizugbe Fertility Scale". Hedefined fertility scale as a tool used to categorize the fertility status of a couple according to the number of their children.

\section{Methodology:}

This is an exploratory study and the respondents were selected by simple random sampling and the researcher chose an interview approach. The respondents met with the interviewers on a face to face basis during the questionnaire administration session. The interview was household based. The study adopted simple tools, which enabled the interviewers interact uninhibited with the respondents, and also made it easy for the respondents to understand the questions they were asked without requiring additional prompting. The variables involved in the study were quantitatively measured after the analysis of the data collected from the fieldwork

This study targeted two groups of women:

(1) Married women resident in the rural villages and

(2) Married women from the same villages as those in (1), but resident in the urban areas.

The entire respondents were women with the following characteristics:

(i) Adult females aged 15yrs and above.

(ii) Has had at least one child who has completed primary education before the date of this interview.

(iii) Would have been resident at the settlement of interview for at least 12 calendar months before the date of the interview.

(iv) The six senatorial districts making up Abia and Imo States were listed and two were selected randomly (one from each state). All the Local Government Areas (LGAs) in the selected senatorial districts were equally listed in stratified form and one LGA was selected from each of the two senatorial districts. These two LGAs randomly selected from the two senatorial districts represented the entire Abia and Imo States. The two LGAs are Orsu and Ohafia.

(v) After the LGAs were selected, the listing of all the Autonomous Communities was done to facilitate the selection of the representative communities. Two Autonomous Communities and their two State Capitals were randomly selected.

(vi) In all 1475 respondents were randomly selected and interviewed. See the table below:

\begin{tabular}{|c|c|c|c|c|c|}
\hline $\begin{array}{l}\text { One selected } \\
\text { States. }\end{array}$ & $\begin{array}{l}\text { Total female popn. } \\
2011 \text {. }\end{array}$ & $\begin{array}{l}25 \% \text { of total female } \\
\text { popn are ever } \\
\text { married. }\end{array}$ & $\begin{array}{ll}\text { Sample } & \\
\text { selected } \quad \text { (rural } \\
60 \% \text { ) }\end{array}$ & $\begin{array}{l}\text { Sample selected } \\
\text { (urban } 40 \% \text { ) }\end{array}$ & $\begin{array}{l}\text { Sample } \\
\text { selected } \\
\text { (total 100\%) }\end{array}$ \\
\hline Imo & $2,209,210$ & 1215066 & 510 & 340 & $510+340=\mathbf{8 5 0}$ \\
\hline \multirow[t]{2}{*}{ Abia } & \multirow[t]{2}{*}{$3,287,439$} & 1808091 & 375 & 250 & $375+250=\mathbf{6 2 5}$ \\
\hline & & & & & 1475 \\
\hline
\end{tabular}


After a thorough study of the world fertility trend, the researcher fashioned out a five scale measure that can be universally accepted as follows:

\begin{tabular}{|ll|l|}
\hline \multicolumn{2}{|l|}{ Fertility scale } & Score \\
\hline 6. & Zero fertility & 0 (No child). \\
\hline 7. & Low fertility, or replacement fertility & $1-2$ children \\
\hline 8. & Medium fertility & $3-4$ children \\
\hline 9. & High fertility & $5-6$ children \\
\hline 10. & Very high fertility & $7+$ children \\
\hline
\end{tabular}

\section{Findings:}

After a cross tabulation of the number of children by the women since being in marriage with their age at first marriage, it was found that women who married at younger age bracket (15-24yrs; with mean score of $46.1 \%$ ) had more children (5-6 children per woman, or high fertility level), than the women who married at later age bracket (25-34yrs; with mean score of 71.5\%), who had 3-4 children per woman (medium fertility level). This justified the age long findings by demographers that the older the age at first marriage, the fewer the number of children ever born.

About two thirds majority $(70.1 \%)$ of the women were of the opinion that both husband and wife usually determine the number of children a woman would have in marriage. However, $23.1 \%$ of the respondents stated that husband only determined the number of children that couples do have.

The rural women were asked to respond to the question "If you were to be living in the city, would you have had the same number of children as you have today?" More than half $54.5 \%$ of the rural women answered "No", claiming that their reasons for the choice of fewer children if they were to be living in the city included: "Things are expensive in the city (43.2), "So that we can afford good training for our children (22.7)" etc.

Over half of the urban women (52.5\%) stated they presently have 3-4 children alive, while $42.4 \%$ said they have 5-6 children alive. This indicates that using Nwizugbe Fertility Scale, the urban women preferred the medium fertility level.

More than half of the respondents (52.5\%) stated that they would prefer 3-4 children (medium fertility level) per woman, if they were given the right of choice because of the circumstances in the city. Another $47.5 \%$ of the respondents said they would prefer 5-6 (47.5\%), that is, the high fertility level. Nobody wanted the very high fertility level ( 7 children and above). The interesting development here is that all the women who presently have 7 children and above opted for 5-6 children if they had a choice to decide.

The women gave various reasons for their fertility scale preferences. $47.5 \%$ of them said they want to be able to provide good training, good care, quality education to their children, $37.3 \%$ said "this is what we desire" and another $11.9 \%$ said "Things are expensive in the city".

\section{Advantages of Nwizugbe Fertility Scale:}

A fertility scale guides the couples, the professionals, the researchers and the policy makers during decision making.

1. Nwizugbe Fertility Scale is a guide to family planning options for the family. This means that couples can be guided to decide how small or how large they would like their family size to be by looking at this scale. The scale can act as a guide to Family Planning Counsellors while interacting with a client during a counselling session.

2. To the professional demographers, economists, and population practitioners, this scale has harmonized their divergences of measuring fertility performances because it has developed a universal statistical quantum to different fertility categories; thus eliminating a rule of the tomb (vague) approach to fertility classification. For example, if a woman says she has a low fertility level, applying this scale, it is easy for someone to understand that she means she has one to two children.

3. To the policy makers, the scale serves as an indicator towards policy options that guides population growth rate.

4. The scale can act as a population growth alert to the Global Communities. In order wards, it can act as a check against over population of a country hence; it can be used to watch over countries fertility trend through her total fertility rate (TFR).

\section{Interpretation of the Nwizugbe Fertility Scale:}

1. Zero fertility: This simply means that the couple has no child. The reasons for this may be biological, health related or by choice. Their population is not distributed by country specific, but can be sported around the globe. However, some countries may have higher tendencies for this fertility scale than others. For example, more couples in Canada, America, Europe and Africa now belong to zero fertility scale for cosmetic purpose. 
Couples who are into same sex marriage also fall into this scale because they by choice cannot bear children, excepting through adoption.

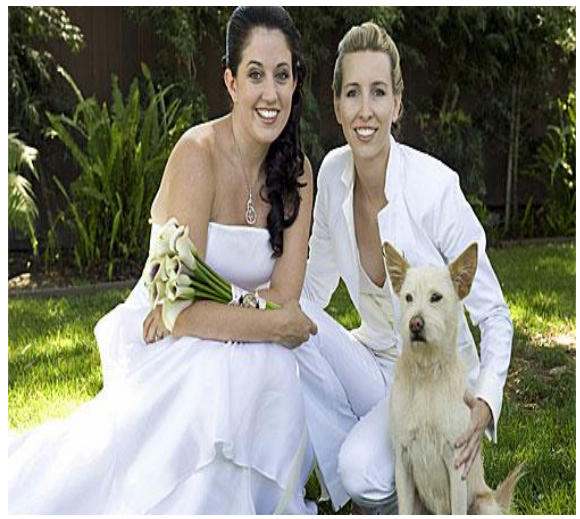

\section{Where Can Gays Legally Marry?}

According to information sourced from internet Google (2011) ${ }^{6}$

- Canada: It is now legal for gays and lesbians to marry every place in Canada.

- Belgium in 2003 became the second country in the world to allow gay and lesbian couples to marry. Since 2006, gay and lesbian couples have been allowed to adopt children.

- Norway became the sixth country to legalize same-sex marriage on May 11, 2008.

- Portugal became the sixth European country to allow same-sex marriage with a law passed by parliament in January 2010 and signed by the president in May. Although same-sex marriage is now legal in Portugal, same-sex couples are not allowed to adopt children.

- Sweden became the seventh country to legalize same-sex marriage on April 1, 2009. Marriage licenses for same-sex couples became available beginning May 1, 2009.

- Netherlands (Holland) has full marriage and registered partnership rights for same sex or opposite sex couples.

- Spain voted in June 2005 to extend full marriage rights to gay and lesbian citizens.
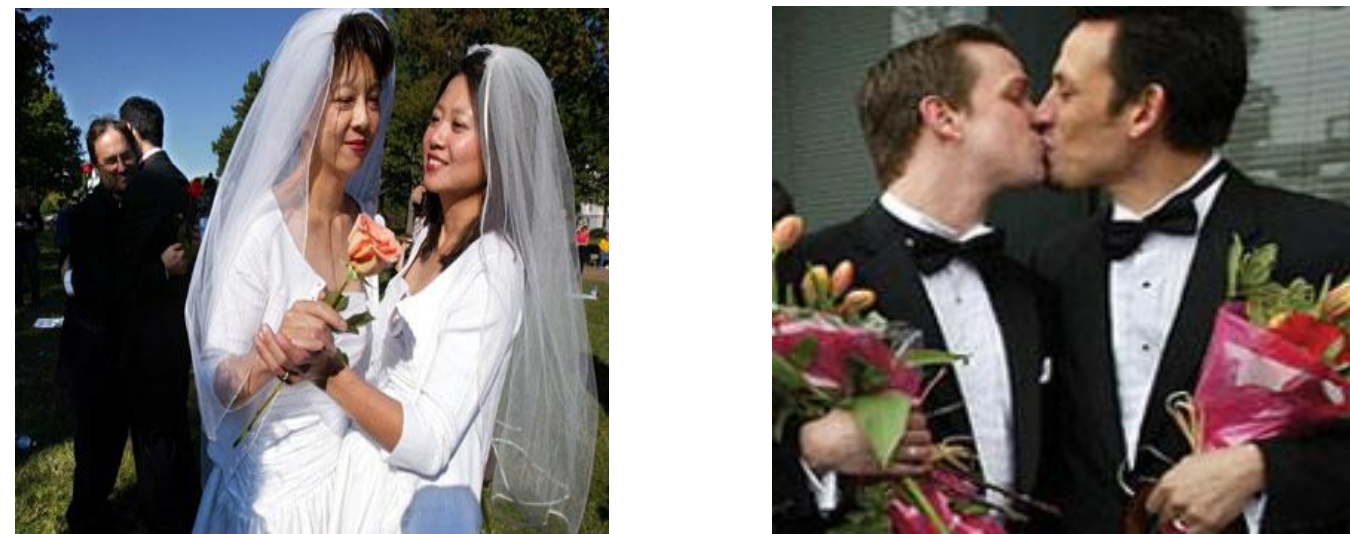

Note: All pictorial illustrations were goggled form the internet.

- Iceland began to allow same-sex marriage in June 2010.

- South Africa legalized gay marriage on November 30th, 2006.

- In the United States gays and lesbians can legally marry in New Hampshire, Massachusetts, Vermont and Washington DC.

- New York, California, Rhode Island, New Mexico and Washington DC recognize marriages by same-sex couples legally performed elsewhere.

- California With the passage of Prop 8, gay and lesbian couples who were married between June and November 2008 are still legally married, but no new legal marriages can be performed in California 


\section{Low fertility or replacement fertility:}

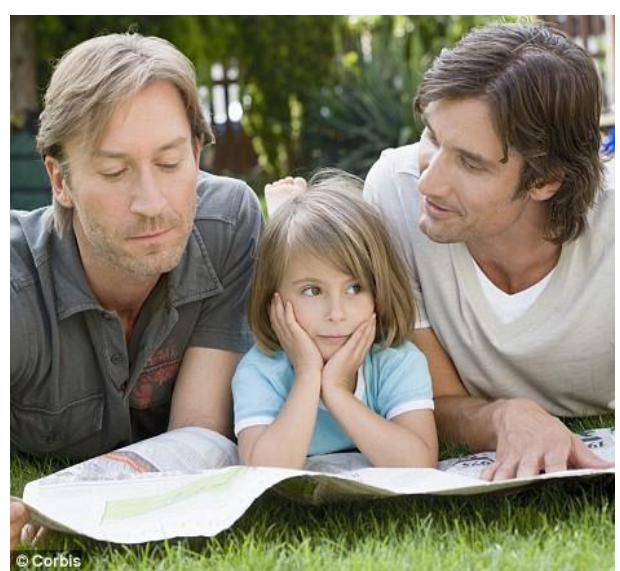

Replacement level fertility is the total number of children born by a couple just to replace their own number in procreativity. In terms of total fertility rate it is 2 children per woman and in terms of net reproductive rate (NRR) it is exactly one child per woman.

According to the statistics released by $\mathbf{U N ~ ( 2 0 1 0 )}{ }^{7}$ and posted to Google (2011) it has been estimated that about $42 \%$ of the world population lives in nations with sub-replacement fertility level. The report further stated that the reason why the countries in this fertility level are experiencing growth is immigration, which is the influx of foreign nationals into the country and increase in longevity (higher life expectancy). These countries can be found in Europe, Canada, Australia, Russia, Iran, Tunisia, China and Japan. Among them, the ones with the lowest fertility rate are Hong Kong, Macau, Singapore, Taiwan, Ukraine and Lithuania. Places like Japan, Lithuania and Ukraine are already experiencing population decline through emigration.

\begin{tabular}{|c|c|c|}
\hline S/No & Country. & TFR \\
\hline 1 & $\ll$ Jamaica & 2.4 \\
\hline 2 & Suriname & 2.4 \\
\hline 3 & Algeria & 2.4 \\
\hline 4 & Morocco & 2.4 \\
\hline 5 & Réunion (France) & 2.4 \\
\hline 6 & $\sum$ Guyana & 2.3 \\
\hline 7 & 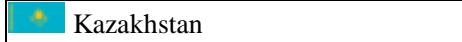 & 2.3 \\
\hline 8 & United Arab Emirates & 2.3 \\
\hline 9 & 2 Grenada & 2.3 \\
\hline 10 & - Brunei & 2.3 \\
\hline 11 & Bahrain & 2.3 \\
\hline 12 & French Polynesia (France) & 2.3 \\
\hline 13 & $\because$ Argentina & 2.3 \\
\hline 14 & Colombia & 2.2 \\
\hline 15 & \begin{tabular}{|l|l|} 
Mexico \\
\end{tabular} & 2.2 \\
\hline 16 & Aebanon & 2.2 \\
\hline 17 & \begin{tabular}{|l|l} 
i & Saint Vincent and the Grenadines \\
\end{tabular} & 2.2 \\
\hline 18 & Bhutan & 2.2 \\
\hline 19 & Kuwait & 2.2 \\
\hline 20 & $\begin{array}{|ll|}\wedge & \text { Saint Lucia } \\
\end{array}$ & 2.2 \\
\hline 21 & \begin{tabular}{|c|} 
Indonesia \\
\end{tabular} & 2.2 \\
\hline 22 & thit United States Virgin Islands (US) & 2.2 \\
\hline 23 & C. Turkey & 2.1 \\
\hline 24 & \begin{tabular}{|ll}
$\star$ & Vietnam \\
\end{tabular} & 2.1 \\
\hline 25 & 三 Uruguay & 2.1 \\
\hline 26 & Guadeloupe (France) & 2.1 \\
\hline
\end{tabular}




\begin{tabular}{|c|c|c|}
\hline 27 & Costa Rica & 2.1 \\
\hline 28 & \begin{tabular}{|ll}
1 & New Caledonia (France) \\
\end{tabular} & 2.1 \\
\hline 29 & Myanmar & 2.1 \\
\hline 30 & Albania & 2.1 \\
\hline 31 & Enited States & 2.1 \\
\hline 32 & 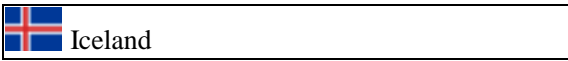 & 2.1 \\
\hline 33 & Aruba (Netherlands) & 2.0 \\
\hline 34 & $=\operatorname{Iran}$ & 2.0 \\
\hline 35 & Bahamas & 2.0 \\
\hline 36 & New Zealand & 2.0 \\
\hline 37 & Ireland & 2.0 \\
\hline 38 & ${ }^{*}$ Chile & 2.0 \\
\hline 39 & \begin{tabular}{|ll}
$\odot$ & Tunisia \\
\end{tabular} & 2.0 \\
\hline 40 & Martinique (France) & 2.0 \\
\hline 41 & $\theta$ Brazil & 2.0 \\
\hline 42 & France & 2.0 \\
\hline 43 & IA Sri Lanka & 2.0 \\
\hline 44 & A Mongolia & 2.0 \\
\hline 45 & Mauritius & 2.0 \\
\hline 46 & Netherlands Antilles (Netherlands) & 2.0 \\
\hline 47 & 0 North Korea & 2.0 \\
\hline 48 & Thailand & 2.0 \\
\hline 49 & ELrway & 2.0 \\
\hline 50 & \begin{tabular}{|l|l|}
$*$ & Montenegro \\
\end{tabular} & 2.0 \\
\hline 51 & = Puerto Rico (US) & 2.0 \\
\hline 52 & Finland & 2.0 \\
\hline 53 & United Kingdom & 2.0 \\
\hline 54 & \begin{tabular}{|l} 
Azerbaijan \\
\end{tabular} & 2.0 \\
\hline 55 & D Denmark & 2.0 \\
\hline 56 & Eneden & 2.0 \\
\hline 57 & Serbia & 2.0 \\
\hline 58 & Australia & 2.0 \\
\hline 58 & \begin{tabular}{|l|l} 
& People's Republic of China (mainland only) \\
\end{tabular} & 2.0 \\
\hline 59 & Netherlands & 2.0 \\
\hline 60 & Luxembourg & 2.0 \\
\hline 61 & Belgium & 2.0 \\
\hline 62 & Trinidad and Tobago & 2.0 \\
\hline 63 & Cyprus & 2.0 \\
\hline 64 & $\|$ Canada & 2.0 \\
\hline 65 & Barbados & 2.0 \\
\hline 66 & Cuba & 1.5 \\
\hline
\end{tabular}




\begin{tabular}{|c|c|c|}
\hline 67 & Estonia & 1.5 \\
\hline 68 & Portugal & 1.5 \\
\hline 68 & Macedonia & 1.4 \\
\hline 69 & Switzerland & 1.4 \\
\hline 70 & Channel Islands ( ${ }_{\text {Jersey and }}$ Guernsey) (UK) & 1.4 \\
\hline 71 & Austria & 1.4 \\
\hline 72 & Spain & 1.4 \\
\hline 73 & $\because \div$ Georgia & 1.4 \\
\hline 74 & \begin{tabular}{|l|l|}
$*$ & Moldova \\
\end{tabular} & 1.4 \\
\hline 75 & Armenia & 1.4 \\
\hline 76 & Italy & 1.4 \\
\hline 77 & Malta & 1.4 \\
\hline 78 & Germany & 1.4 \\
\hline 79 & $E_{\text {Croatia }}$ & 1.4 \\
\hline 80 & Russia & 1.3 \\
\hline 81 & Ereece & 1.3 \\
\hline 82 & Bulgaria & 1.3 \\
\hline 83 & Romania & 1.3 \\
\hline 84 & Latvia & 1.3 \\
\hline 85 & Hungary & 1.3 \\
\hline 86 & Slovenia & 1.3 \\
\hline 87 & - Japan & 1.3 \\
\hline 88 & Lithuania & 1.3 \\
\hline 89 & \begin{tabular}{|l|} 
\\
Singapore
\end{tabular} & 1.3 \\
\hline 90 & \begin{tabular}{|ll}
9 & Slovakia \\
\end{tabular} & 1.3 \\
\hline 91 & Czech Republic & 1.2 \\
\hline 92 & Bosnia and Herzegovina & 1.2 \\
\hline 93 & Poland & 1.2 \\
\hline 94 & \begin{tabular}{|l|} 
Ukraine \\
\end{tabular} & 1.2 \\
\hline 95 & "o: South Korea & 1.2 \\
\hline 96 & Belarus & 1.2 \\
\hline 97 & *t Hong Kong (PRC) & 1.0 \\
\hline 98 & * Macau (PRC) & 1.0 \\
\hline
\end{tabular}

\section{Medium fertility:}

This is the fertility scale neither low enough to be classified as replacement level nor high enough to be regarded as high fertility scale. The fertility scale is 3-4 children per woman. Below are the lists of countries in this fertility scale. Source of data (UN 2010, ibid) 
Nwizugbe Fertility Scale.

\begin{tabular}{|c|c|c|}
\hline S/No & Country. & TFR \\
\hline \begin{tabular}{|l||}
1 \\
\end{tabular} & \begin{tabular}{|ll} 
& Mauritania \\
\end{tabular} & 4.4 \\
\hline 2 & \begin{tabular}{|ll} 
- Cameroon \\
\end{tabular} & 4.3 \\
\hline 3 & - Comoros & 4.3 \\
\hline 4 & Iraq & 4.3 \\
\hline 5 & Sudan & 4.2 \\
\hline 6 & \begin{tabular}{|l|l|} 
" & Guatemala \\
\end{tabular} & 4.2 \\
\hline 7 & $2 \quad$ Djibouti & 4.0 \\
\hline 8 & \begin{tabular}{|l|l|} 
& Samoa \\
\end{tabular} & 4.0 \\
\hline 9 & Solomon Islands & 4.0 \\
\hline 10 & $\ldots$ Sao Tome and Principe & 4.0 \\
\hline 11 & \pm Ghana & 4.0 \\
\hline 12 & \begin{tabular}{|l|l|}
+ & Tonga \\
\end{tabular} & 4.0 \\
\hline 13 & 20 Papua New Guinea & 4.0 \\
\hline 14 & $\sum$ Vanuatu & 4.0 \\
\hline 15 & $\begin{array}{|ll|} & \text { Federated States of Micronesia } \\
\end{array}$ & 4.0 \\
\hline 16 & $\begin{array}{|ll|} & \text { Haiti } \\
\end{array}$ & 4.0 \\
\hline 17 & C. Pakistan & 4.0 \\
\hline 18 & Bolivia & 4.0 \\
\hline 19 & $\$$ Swaziland & 4.0 \\
\hline 20 & 2 Lesotho & 3.4 \\
\hline 21 & - Cape Verde & 3.4 \\
\hline 22 & Saudi Arabia & 3.4 \\
\hline 23 & ETajikistan & 3.4 \\
\hline 24 & Honduras & 3.4 \\
\hline 25 & E Nepal & 3.3 \\
\hline 26 & \begin{tabular}{|l|l} 
French Guiana (France) \\
\end{tabular} & 3.3 \\
\hline 27 & $\sum$ Philippines & 3.2 \\
\hline 28 & \begin{tabular}{|l|l|} 
& Laos- \\
\end{tabular} & 3.2 \\
\hline 29 & Namibia & 3.2 \\
\hline 30 & \#Zimbabwe & 3.2 \\
\hline 31 & 幽 Cambodia & 3.1 \\
\hline 32 & $=$ Jordan & 3.1 \\
\hline 33 & Paraguay & 3.1 \\
\hline 34 & Syria & 3.1 \\
\hline 35 & Gabon & 3.1 \\
\hline 36 & Oman & 3.0 \\
\hline 37 & Q Belize & 3.0 \\
\hline 38 & Botswana & 3.0 \\
\hline
\end{tabular}


Nwizugbe Fertility Scale.

\begin{tabular}{|c|c|c|}
\hline 39 & Egypt & 3.0 \\
\hline 40 & Bangladesh & 3.0 \\
\hline 41 & Fominican Republic & 3.0 \\
\hline 42 & India & 3.0 \\
\hline 43 & Nicaragua & 3.0 \\
\hline 44 & Fiji & 3.0 \\
\hline 45 & Israel & 3.0 \\
\hline 46 & Libya & 3.0 \\
\hline 47 & $\bar{x}$ Western Sahara & 3.0 \\
\hline 48 & El Salvador & 3.0 \\
\hline 49 & Qatar & 3.0 \\
\hline 50 & $\geqslant$ South Africa & 3.0 \\
\hline 51 & \begin{tabular}{|ll}
1 & Maldives \\
\end{tabular} & 3.0 \\
\hline 52 & Malaysia & 3.0 \\
\hline 53 & Ecuador & 3.0 \\
\hline 54 & $\div$ Panama & 3.0 \\
\hline 55 & Venezuela & 3.0 \\
\hline 56 & \begin{tabular}{|l|l|} 
Guam (US) \\
\end{tabular} & 3.0 \\
\hline 57 & \begin{tabular}{|l|l} 
Peru \\
\end{tabular} & 3.0 \\
\hline 58 & $\begin{array}{ll} & \text { Turkmenistan } \\
\end{array}$ & 3.0 \\
\hline 59 & Uzbekistan & 3.0 \\
\hline \multirow[t]{2}{*}{60} & Kyrgyzstan & 3.0 \\
\hline & **World Average & 3.0 \\
\hline
\end{tabular}

\section{High fertility:}

This is the fertility scale really high but not too high. The total fertility level classified into this scale is 5-6 children per woman. The lists of countries in this scale according to UN (2010, op cit) include;

\begin{tabular}{|c|c|c|}
\hline S/No & Country & TFR \\
\hline 1 & $\begin{array}{|ll|}2 & \text { Angola } \\
\end{array}$ & 6.4 \\
\hline 2 & \begin{tabular}{|l|l|} 
Chad \\
\end{tabular} & 6.2 \\
\hline 3 & * Somalia & 6.0 \\
\hline 4 & \begin{tabular}{|ll}
$\cdot$ & Burkina Faso \\
\end{tabular} & 6.0 \\
\hline 5 & \begin{tabular}{|l} 
Rwanda \\
\end{tabular} & 6.0 \\
\hline 6 & $\because$ Malawi & 6.0 \\
\hline 7 & Yemen & 6.0 \\
\hline 8 & \begin{tabular}{|l|l|} 
Guinea \\
\end{tabular} & 5.4 \\
\hline 9 & \begin{tabular}{|l|} 
Benin \\
\end{tabular} & 5.4 \\
\hline 10 & Equatorial Guinea & 5.4 \\
\hline 11 & \begin{tabular}{|l|l|} 
Nigeria \\
\end{tabular} & 5.3 \\
\hline 12 & Ethiopia & 5.3 \\
\hline
\end{tabular}


Nwizugbe Fertility Scale.

\begin{tabular}{|c|c|c|}
\hline 13 & I Zambia & 5.2 \\
\hline 14 & Tanzania & 5.2 \\
\hline 15 & Mozambique & 5.1 \\
\hline 16 & Palestinian territories & 5.1 \\
\hline 17 & \begin{tabular}{|l|} 
Eritrea \\
\end{tabular} & 5.1 \\
\hline 18 & Kenya & 5.1 \\
\hline 19 & Togo & 5.1 \\
\hline 20 & Madagascar & 5.0 \\
\hline 21 & Gambia & 5.0 \\
\hline 22 & \begin{tabular}{|l|l|}
$\cdot$ & Senegal \\
\end{tabular} & 5.0 \\
\hline 23 & Fentral African Republic & 5.0 \\
\hline 24 & Republic of the Congo & 5.0 \\
\hline 25 & Côte d'Ivoire & 5.0 \\
\hline
\end{tabular}

\section{Very high fertility:}

This is the fertility level considered too high for modern day socio-economic and health benefits of a woman. The fertility level classified into this scale are 7 children and above per woman. By UN classification of countries, the lists of countries below are in this scale:

\begin{tabular}{|l|l|l|}
\hline S/No & Country & TFR \\
\hline 1 & Niger & 7.2 \\
\hline 2 & Guinea-Bissau & 7.1 \\
\hline 3 & Afghanistan & 7.1 \\
\hline 4 & Burundi & 7.0 \\
\hline 5 & Liberia & 7.0 \\
\hline 6 & Democratic Republic of the Congo & 7.0 \\
\hline 7 & East Timor & 7.0 \\
\hline 8 & Mali & 7.0 \\
\hline 9 & Sierra Leone & 7.0 \\
\hline \hline 10 & OW $_{\text {Uganda }}$ & 7.0 \\
\hline
\end{tabular}

\section{Conclusion:}

The above classification can be used to measure the world fertility dynamics. Thomas Robert Malthus $(1766-1834)^{8}$ was a British Economist and a Demographer, whose famous theory of population highlighted the potential dangers of over-population. In his famous writing "An Essay on the Principles of Population", Malthus stated that every nation would necessarily pass through a period of very high fertility increase first, before settling down to low fertility level. (Unfortunately, he never defined what statistical quantity of fertility level constituted very high and very low fertility, but based his assertion upon what he described as over population targeting sustainability. To Malthus, food was growing at an arithmetic progression, while human procreation was growing at a geometric progression. What this means in literal terms, is that human beings were increasing in number faster than food supply. This meant that if no deliberate policy was put in place to control population growth, one day, human population would outgrow food production. This he described as over-population. When a nation suffers over-population, there are several reactions which the inhabitants can make; adopt a population reduction policy, out-migrate to new land, increase agricultural productivity by mechanical means, or face what Malthus described as the ultimate; "famine or disease" which will eventually consume the population. 
According to Malthus, disease, food shortage and death due to starvation, were nature's way to control population. He proposed that human beings adopt measures like infanticide, abortion, delay in marriage and strictly following celibacy to check population growth.

Malthus views opposed that of other scholars like Marquis de Condorcet and William Godwin who saw rapid population growth in England during the period of industrial revolution as an advantage to the society. In his book The Enquirer, William Godwin promoted population growth as a means for human beings to attain equality. According to him, an increased population would create more wealth that would provide food for the whole humanity. In contrast to this viewpoint, Malthus interpreted overpopulation as an evil that would reduce the amount of food available per person. By the end of the 19th Century, living standards improved and birth rates dropped in the Western countries, the concerns of overpopulation became less relevant to philosophers and economists. However, in the developing countries like Nigeria, which are majorly dependent on unprocessed food and crude oil, Malthus' theory often finds credibility.

One great critique of Malthus was Karl Marx who lived from 1818 to 1883 . He was a German philosopher, social scientist, historian and revolutionary, and is without a doubt the most influential socialist thinker to emerge in the 19th century. Karl Marx (1844) ${ }^{9}$ argued that Malthus failed to recognize the potential of human population to increase food supply. Malthus is accused by many to have failed to comprehend man's ability to use science and technology to increase food supply to meet the needs of an increasing population.

Emile Durkheim $(1858-1917)^{10}$ was a French Sociologist considered by many as the father of Sociology. He argued that if a nation is faced with over-population, her citizens can react positively by way of increasing food production through the application of modern science and technology, or the people will outmigrate, explore new land through territorial expansion, or face civil war, which will eventually reduce the population size.

This researcher is therefore of the opinion that the gap in all the arguments put forward by the philosophers discussed above is their inability to forecast what must be visible for people to begin to anticipate over-population, and begin to put deliberate measures in place to counter the consequences. One major way of doing this is to use Nwizugbe fertility scale. Once a nation is consistently maintaining high fertility level, then the doom of over population may not be too far from it. The scale therefore becomes a mile stone for deriving indicators to measuring fertility changes and their likely implications for the people. Nwizugbe fertility scale ultimately becomes the meter which nations should adopt to constantly put their population growth in check through promoting medium fertility level.

\section{References:}

[1] Judith Blake, Blake, J. (1981). Family Size and the Quality of Children.Demography 18(4): 421-442. School of Public Health and Department of Sociology, University of California, Los Angeles, California, 90024.

[2] Chuks Iloegbunam (August 2011), The perils of Babangidaismhttp://www.thenigerianvoice.com/nvnews/59468/1/the-perils-ofbabangidaism-by-chuks-iloegbunam.html

[3] Wikipedia (2009). Total fertility rate definition from CIA world factbook, http://en.wikipedia.org/wiki/Total_fertility_rate

[4] Nwaizugbe (2005). Rural Outmigration and Fertility Levels, case of Orsu LGA. M.Phil Thesis, University of Benin, Nigeria.

[5] James Kaphuka (2011). Fertility Rate.http://www.measuredhs.com/pubs/pdf/fr175/04chapter04.pdf

[6] Google (2011) http://lesbianlife.about.com/cs/wedding/a/wheremarriage.htm

[7] United Nation Population Fund (2010). http://en.wikipedia.org/wiki/sex_ratio

[8] Malthus (1798). An Essay on the Principle of Population (1st ed. 1798), online at the Library of Economics and Liberty, http://www.econlib.org/library/Malthus/malPop.html; 6th ed. 1826, online at the Library of Economics and Liberty, http://www.econlib

[9] Karl Marx (1844) http://www.historyguide.org/intellect/marx.html

[10] Émile Durkheim (1957). http://en.wikipedia.org/wiki/emile_Durkheim

[11] http://www.emile-durkheim.com/ 